\title{
Vitamin D status of dairy cattle: Outcomes of current practices in the dairy industry
}

\author{
Corwin D. Nelson, ${ }^{* 1}$ John D. Lippolis, $†$ Timothy A. Reinhardt, $\nmid$ Randy E. Sacco, $†$ Jessi L. Powell,* \\ Mary E. Drewnoski,ł Matthew O’Neil,\# Donald C. Beitz,\# and William P. Weiss§ \\ *Department of Animal Sciences, University of Florida, Gainesville 32611 \\ †Ruminant Diseases and Immunology Research Unit, National Animal Disease Center, USDA Agricultural Research Service, Ames, IA 50010 \\ $\ddagger$ Animal Science Department, University of Nebraska, Lincoln 68583 \\ \#Department of Animal Science, lowa State University, Ames 50011 \\ §Department of Animal Sciences, Ohio Agricultural Research and Development Center, The Ohio State University, Wooster 44691
}

\begin{abstract}
The need for vitamin D supplementation of dairy cattle has been known for the better part of the last century and is well appreciated by dairy producers and nutritionists. Whether current recommendations and practices for supplemental vitamin $\mathrm{D}$ are meeting the needs of dairy cattle, however, is not well known. The vitamin $\mathrm{D}$ status of animals is reliably indicated by the concentration of the 25-hydroxyvitamin D [25(OH)D] metabolite in serum or plasma, with a concentration of $30 \mathrm{ng} / \mathrm{mL}$ proposed as a lower threshold for sufficiency. The objective of this study was to determine the typical serum $25(\mathrm{OH}) \mathrm{D}$ concentrations of dairy cattle across various dairy operations. The serum 25(OH) D concentration of 702 samples collected from cows across various stages of lactation, housing systems, and locations in the United States was $68 \pm 22 \mathrm{ng} /$ $\mathrm{mL}$ (mean \pm standard deviation), with the majority of samples between 40 and $100 \mathrm{ng} / \mathrm{mL}$. Most of the 12 herds surveyed supplemented cows with 30,000 to $50,000 \mathrm{IU}$ of vitamin $\mathrm{D}_{3} / \mathrm{d}$, and average serum $25(\mathrm{OH})$ $\mathrm{D}$ of cows at 100 to 300 DIM in each of those herds was near or above $70 \mathrm{ng} / \mathrm{mL}$ regardless of season or housing. In contrast, average serum $25(\mathrm{OH}) \mathrm{D}$ of a herd supplementing with $20,000 \mathrm{IU} / \mathrm{d}$ was $42 \pm 15 \mathrm{ng} / \mathrm{mL}$, with $22 \%$ below $30 \mathrm{ng} / \mathrm{mL}$. Cows in early lactation $(0$ to $30 \mathrm{~d}$ in milk) also had lower serum $25(\mathrm{OH}) \mathrm{D}$ than did mid- to late-lactation cows $(57 \pm 17$ vs. $71 \pm 20$ $\mathrm{ng} / \mathrm{mL}$, respectively). Serum $25(\mathrm{OH}) \mathrm{D}$ of yearling heifers receiving 11,000 to $12,000 \mathrm{IU}$ of vitamin $\mathrm{D}_{3} / \mathrm{d}$ was near that of cows at $76 \pm 15 \mathrm{ng} / \mathrm{mL}$. Serum $25(\mathrm{OH}) \mathrm{D}$ concentrations of calves, on the other hand, was $15 \pm$ $11 \mathrm{ng} / \mathrm{mL}$ at birth and remained near or below $15 \mathrm{ng} /$ $\mathrm{mL}$ through $1 \mathrm{mo}$ of age if they were fed pasteurized
\end{abstract}

Received July 11, 2016.

Accepted August 21, 2016.

${ }^{1}$ Corresponding author: cdnelson@ufl.edu waste milk with little to no summer sun exposure. In contrast, serum $25(\mathrm{OH}) \mathrm{D}$ of calves fed milk replacer containing 6,600 and $11,000 \mathrm{IU}$ of vitamin $\mathrm{D}_{2} / \mathrm{kg}$ of dry matter were $59 \pm 8$ and $98 \pm 33 \mathrm{ng} / \mathrm{mL}$, respectively, at 1 mo of age. Experimental data from calves similarly indicated that serum $25(\mathrm{OH}) \mathrm{D}$ achieved at approximately 1 mo of age would increase 6 to $7 \mathrm{ng} / \mathrm{mL}$ for every $1,000 \mathrm{IU}$ of vitamin $\mathrm{D}_{3} / \mathrm{kg}$ of dry matter of milk replacer. In conclusion, vitamin D status of dairy cattle supplemented with vitamin $\mathrm{D}_{3}$ according to typical practices, about 1.5 to 2.5 times the National Research Council recommendation, is sufficient as defined by serum 25(OH)D concentrations. Newborn calves and calves fed milk without supplemental vitamin $\mathrm{D}_{3}$, however, are prone to deficiency.

Key words: vitamin D, dairy cattle

\section{INTRODUCTION}

The requirement of vitamin $\mathrm{D}$ for normal growth and development of cattle was established not long after the discovery of the fat-soluble factor that prevented rickets (Rupel et al., 1932; Bechdel et al., 1935; Wallis, 1937). The minimal requirement of 6.7 IU of vitamin $\mathrm{D} / \mathrm{kg}$ of BW was originally established as the amount needed to prevent rickets in calves (Huffman and Duncan, 1935; Bechdel et al., 1937). Eventually, it was established that vitamin D was not simply a nutrient required for normal skeletal growth and development; rather, it served as a precursor to an intricate endocrine mechanism that maintained $\mathrm{Ca}$ and $\mathrm{P}$ concentrations in blood (Lund and DeLuca, 1966; Fraser and Kodicek, 1970; DeLuca, 1971). More recently, vitamin D has been shown to have multiple physiological roles, such as control of cellular differentiation and proliferation and activation of innate immune defenses (Norman, 2008; Adams and Hewison, 2010; Nelson et al., 2012). The newfound roles of vitamin $\mathrm{D}$, along with its critical role in $\mathrm{Ca}$ and $\mathrm{P}$ homeostasis, highlight the need to examine 
current practices for vitamin D supplementation in the dairy industry and question whether current recommendations are adequate for dairy cattle.

Cattle naturally acquire vitamin $\mathrm{D}$ as vitamin $\mathrm{D}_{2}$ from plant-associated fungi or as vitamin $\mathrm{D}_{3}$ that is synthesized endogenously in sun-exposed skin from 7-dehydrocholesterol. Cattle acquire appreciable amounts of vitamin $\mathrm{D}_{2}$ from forages. Alfalfa hay, for instance, can contain as much as $2,500 \mathrm{IU}$ of vitamin $\mathrm{D}_{2} / \mathrm{kg}$ of $\mathrm{DM}$ and corn silage can contain approximately $500 \mathrm{IU}$ of vitamin $\mathrm{D}_{2} / \mathrm{kg}$ of DM (Wallis et al., 1958; Horst et al., 1984). The vitamin $\mathrm{D}_{2}$ content within forage types is highly variable (160 to $2,500 \mathrm{IU} / \mathrm{kg}$ of $\mathrm{DM}$ for alfalfa hay), however, which excludes forages as a consistent source of vitamin D. Vitamin $\mathrm{D}_{2}$ also is not metabolized as efficiently as vitamin $\mathrm{D}_{3}$ (Sommerfeldt et al., 1983; Hymøller and Jensen, 2011); rather, vitamin $\mathrm{D}_{3}$ metabolites are the major form circulating in blood of cattle exposed to summer sun (Horst and Littledike, 1982), and supplemental vitamin D is most often provided to cattle as vitamin $\mathrm{D}_{3}$.

Vitamin $\mathrm{D}_{2}$ and vitamin $\mathrm{D}_{3}$ are readily converted by 25 -hydroxylases to 25-hydroxyvitamin D [25( $\mathbf{O H}) \mathbf{D}$; refers to $\mathrm{D}_{2}$ or $\mathrm{D}_{3}$ metabolite if no subscript is given]. The concentration of $25(\mathrm{OH}) \mathrm{D}$ in serum or plasma is the best indicator of the vitamin $\mathrm{D}$ status of an animal. Similar to humans, circulating $25(\mathrm{OH}) \mathrm{D}$ concentrations of 20 to $50 \mathrm{ng} / \mathrm{mL}$ of serum have traditionally been described as normal for cattle, with concentrations below $10 \mathrm{ng} / \mathrm{mL}$ indicative of vitamin D deficiency (Horst et al., 1994; Norman, 2008). However, humans and cattle that receive abundant exposure to summer sun (i.e., lifeguards or cattle on pasture) without vitamin D supplementation have serum $25(\mathrm{OH}) \mathrm{D}$ concentrations between 40 to $100 \mathrm{ng} / \mathrm{mL}$ (Hollis, 2005; Casas et al., 2015; Nelson et al., 2016).

The $25(\mathrm{OH}) \mathrm{D}$ metabolite is the precursor to the active hormone, 1,25-dihydroxyvitamin $\mathrm{D}\left[\mathbf{1 , 2 5}(\mathbf{O H})_{2} \mathrm{D}\right]$ that acts to upregulate expression of genes related to calcium binding and transport, bone remodeling, and innate host-defense, among others. Concentrations of $1,25(\mathrm{OH})_{2} \mathrm{D}$ in circulation are tightly controlled between 20 to $100 \mathrm{pg} / \mathrm{mL}$, even at low (i.e., 10 to $20 \mathrm{ng} /$ $\mathrm{mL}) 25(\mathrm{OH}) \mathrm{D}$ concentrations (Rajaraman et al., 1997; Nonnecke et al., 2009), in response to the endocrine system that controls $\mathrm{Ca}$ and $\mathrm{P}$ homeostasis. In contrast, low concentrations of $25(\mathrm{OH}) \mathrm{D}$ impair synthesis of $1,25(\mathrm{OH})_{2} \mathrm{D}$ by immune cells in response to pathogens (Liu et al., 2006; Nelson et al., 2010; Merriman et al., 2015). The minimal $25(\mathrm{OH}) \mathrm{D}$ concentration required for optimal immune function in cattle has not been defined, but $25(\mathrm{OH}) \mathrm{D}$ concentrations below $30 \mathrm{ng} / \mathrm{mL}$ have been hypothesized to represent a state of vitamin
D insufficiency (Hollis, 2005; Norman, 2008; Adams and Hewison, 2010; Nelson et al., 2012).

In the absence of data defining the $25(\mathrm{OH}) \mathrm{D}$ concentrations required for optimal health and productivity, the $25(\mathrm{OH}) \mathrm{D}$ concentrations of animals on summer pasture provide an approximate target. The range of 20 to $50 \mathrm{ng} / \mathrm{mL}$ that was originally defined as normal for cattle was based on the $25(\mathrm{OH}) \mathrm{D}$ concentrations of a few seemingly healthy cattle (Horst and Littledike, 1982). In contrast, more recent reports have shown that serum $25(\mathrm{OH}) \mathrm{D}$ concentrations of beef calves coming off summer pasture without vitamin D supplementation are between 50 to $60 \mathrm{ng} / \mathrm{mL}$, on average, whereas those of beef cows are between 70 to $80 \mathrm{ng} / \mathrm{mL}$. Those values are based on nearly 300 calves and 30 cows from multiple locations in the United States and suggest that normal serum $25(\mathrm{OH}) \mathrm{D}$ concentrations of cattle in natural settings are somewhat higher than those originally reported.

Just as the serum $25(\mathrm{OH}) \mathrm{D}$ concentrations required for health of cattle are not well-defined, so are the recommendations of supplemental vitamin D. Wallis (1946) proposed that lactating cattle should receive 12,000 to 15,000 IU of supplemental vitamin D. The NRC (2001) recommends 21,000 IU supplemental vitamin $\mathrm{D}_{3} / \mathrm{d}$ ( $\sim 800$ to $1,000 \mathrm{IU} / \mathrm{kg}$ of $\mathrm{DM})$ for lactating Holstein cows (calculated for $680 \mathrm{~kg}$ of BW). Dairy producers instead typically provide lactating cows with 30,000 to $50,000 \mathrm{IU}$ of vitamin $\mathrm{D}_{3}$ (Weiss, 1998). The NRC (2001) recommends about $300 \mathrm{IU}$ of vitamin $\mathrm{D}_{3} / \mathrm{d}(600$ $\mathrm{IU} / \mathrm{kg}$ of DM) for dairy calves, the minimum necessary to prevent rickets in calves (Bechdel et al., 1937). Milk replacers, on the other hand, typically contain 11,000 $\mathrm{IU} / \mathrm{kg}$ of DM. The NRC recommendation and current practices for cows and calves, however, are not based on dose titration studies or corresponding serum $25(\mathrm{OH}) \mathrm{D}$ concentrations. Whether or not the recommendations and practices for vitamin D supplementation of dairy cattle are adequate or excessive is largely unknown.

The objective of our study was to assess serum $25(\mathrm{OH})$ D concentrations of dairy cattle fed and managed according to typical industry practices with the goal of ascertaining the appropriateness of current practices in the dairy industry. Serum samples were collected from dairy cattle from 12 dairy herds across different management practices and locations in the United States and analyzed for concentrations of $25(\mathrm{OH}) \mathrm{D}$. Serum $25(\mathrm{OH}) \mathrm{D}$ concentrations from experiments with dairy calves also were analyzed to develop predictions of serum $25(\mathrm{OH}) \mathrm{D}$ in response to supplemental vitamin $\mathrm{D}$ as a guide for vitamin D supplementation of calves. Altogether, our study provides a formative assessment of serum $25(\mathrm{OH}) \mathrm{D}$ concentrations of dairy cattle fed 
and managed according to typical industry practices and identifies needs and opportunities for improvement of health and productivity through vitamin D supplementation.

\section{MATERIALS AND METHODS}

All procedures were performed according to animal care protocols approved at each respective institution involved in accordance with accepted principles and guidelines for care and use of animals in research (FASS, 2010).

\section{Survey of Serum 25(OH)D Concentrations}

Blood samples were collected from dairy cows in 12 dairy herds across different management practices and locations in the United States (Table 1). Information regarding housing, time spent outdoors, season of sample collection, and estimated supplemental vitamin $\mathrm{D}_{3}$ were collected. All of the herds consisted of Holstein cows, except herd 6, which consisted of approximately $50 \%$ Holstein cows and 50\% Jersey cows. Blood samples were collected in April from 2 herds in southeastern United States from Holstein heifers approximately $1 \mathrm{yr}$ of age, along with samples from preweaned Holstein calves from 6 farms using various management and housing practices. Blood samples from preweaned calves were collected after colostrum consumption.

Blood samples were either transported or shipped to the laboratory where serum was collected and stored at $-20^{\circ} \mathrm{C}$ until analysis. Serum $25(\mathrm{OH}) \mathrm{D}$ concentra- tions were measured using validated RIA (DiaSorin, Stillwater, MN) or ELISA methods (VID3-K01, Eagle BioScience, Nashua, NH). The assays were performed as previously reported using standards prepared in vitamin D-deficient bovine calf serum (Hollis et al., 1993; Nelson et al., 2016). The data were analyzed using GraphPad Prism (GraphPad Software Inc., La Jolla, $\mathrm{CA}$ ) to determine the mean and variance of serum $25(\mathrm{OH}) \mathrm{D}$ of cows and heifers. Comparisons of $25(\mathrm{OH})$ D across stage of lactation, season of collection, supplemental vitamin $\mathrm{D}$, or age of calves were performed by using the mixed procedure of SAS (version 9.3, SAS Institute Inc., Cary, NC) with animal within herd as a random variable.

\section{Effects of Dietary Supplemental Vitamin $D_{3}$ on Serum 25(OH)D of Calves}

Two experiments were conducted at the USDA National Animal Disease Center in Ames, Iowa, where Holstein bull calves were fed milk replacer containing 1,700 or $17,900 \mathrm{IU}$ of vitamin $\mathrm{D}_{3} / \mathrm{kg}$ of milk replacer powder in one experiment, and 400 or 11,000 IU of vitamin $\mathrm{D}_{3} / \mathrm{kg}$ of milk replacer powder in a second experiment. The milk replacer was formulated to meet NRC recommendations for dairy calves and fed to achieve a medium rate of growth according to model predictions (NRC, 2001). The calves received colostrum at birth and were housed indoors and raised strictly on a milk replacer diet from 2 to $3 \mathrm{~d}$ of age up to $10 \mathrm{wk}$ in the first experiment and 6 wk of age in the second experiment. Serum samples were collected from the calves

Table 1. Serum 25-hydroxyvitamin D $[25(\mathrm{OH}) \mathrm{D}]$ concentrations of dairy cows ${ }^{1}$

\begin{tabular}{|c|c|c|c|c|c|c|c|}
\hline Herd & $\begin{array}{l}\text { Herd } \\
\text { size }\end{array}$ & $\begin{array}{c}\text { No. of } \\
\text { samples }\end{array}$ & $\begin{array}{l}\text { Herd } \\
\text { location }\end{array}$ & $\begin{array}{c}\text { Supplemental } \\
\text { vitamin } \mathrm{D}^{2}(\mathrm{kIU})\end{array}$ & $\begin{array}{c}\text { Time outside } \\
(\mathrm{h})\end{array}$ & $\begin{array}{l}\text { Months of } \\
\text { collection }^{4}\end{array}$ & $\begin{array}{l}\text { Serum } 25(\mathrm{OH}) \\
\mathrm{D}^{5}(\mathrm{ng} / \mathrm{mL})\end{array}$ \\
\hline 1 & 100 & 92 & WI & 49 & 2 & $3,6,9,12$ & $72 \pm 23$ \\
\hline 2 & 90 & 11 & MN & 30 & 8 & 9 & $69 \pm 16$ \\
\hline 3 & 200 & 271 & WI & 35 & $<1$ & $3,6,9,12$ & $63 \pm 22$ \\
\hline 4 & 50 & 26 & WI & 31 & $<1$ & $3,6,9,12$ & $71 \pm 24$ \\
\hline 5 & 60 & 29 & MN & 30 & 8 & 9,12 & $71 \pm 18$ \\
\hline 6 & 160 & 139 & WI & 43 & 4 & $3,6,9,12$ & $69 \pm 16$ \\
\hline 7 & 120 & 20 & $\mathrm{OH}$ & 30 & $<1$ & 12 & $104 \pm 18$ \\
\hline 8 & 400 & 12 & IA & 35 & $<1$ & 5,10 & $71 \pm 10$ \\
\hline 9 & 4,000 & 16 & $\mathrm{FL}$ & 47 & $<1$ & 4 & $81 \pm 17$ \\
\hline 10 & 5,000 & 22 & $\mathrm{FL}$ & 47 & $<1$ & 4 & $85 \pm 14$ \\
\hline 11 & 2,500 & 24 & GA & 36 & $<1$ & 4 & $81 \pm 15$ \\
\hline 12 & 500 & 32 & FL & 20 & $<1$ & 2 & $42 \pm 15$ \\
\hline Total & & 702 & & & & & $68 \pm 22$ \\
\hline
\end{tabular}

${ }^{1}$ Data represent lactating cows from 0 to 300 DIM and pregnant, nonlactating cows.

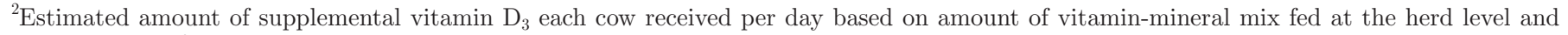
concentration of vitamin $\mathrm{D}_{3}$ in the mix.

${ }^{3}$ Estimated time the herd spent outdoors each day during daylight hours.

${ }^{4}$ Represents the months within the calendar year in which serum samples were collected from each herd.

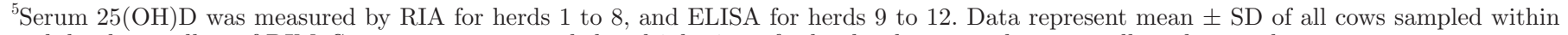
each herd regardless of DIM. Some cows were sampled multiple times for herds where samples were collected more than once. 
every 3 to $4 \mathrm{~d}$ and $25(\mathrm{OH}) \mathrm{D}$ was measured by RIA, as previously described (Hollis et al., 1993). The serum $25(\mathrm{OH}) \mathrm{D}$ data were analyzed by using a mixed model with experiment, dose of vitamin $\mathrm{D}_{3}$, age, dose $\times$ age, and dose $\times$ age $^{2}$ were included as fixed effects and calf nested within treatment as a random effect. The effect of experiment was not significant, so it was removed from the final version of the model. Serum $25(\mathrm{OH}) \mathrm{D}$ data of the calves at $\geq 30 \mathrm{~d}$ of age, where serum $25(\mathrm{OH})$ $\mathrm{D}$ concentrations reached a plateau, were also analyzed without age in the model to determine the main effect of dose on serum $25(\mathrm{OH}) \mathrm{D}$.

\section{Effects of Subcutaneous Vitamin $D_{3}$ Injection on Serum 25(OH)D of Calves}

The response of calves to a bolus injection of vitamin $\mathrm{D}_{3}$ at birth was modeled by using data from multiple experiments. In the first experiment, 9 Holstein bull calves 0 to $2 \mathrm{~d}$ of age at the University of Florida Dairy Unit (Hague, FL) were subcutaneously injected with either 0 or 30,000 IU of vitamin $\mathrm{D}_{3}$ (Cayman Chemical, Ann Arbor, MI; diluted in $1 \mathrm{~mL}$ of ethanol). In the second experiment, 16 Holstein bull calves 0 to $2 \mathrm{~d}$ of age at the University of Florida Dairy Unit were subcutaneously injected with either $0,80,000$, or 120,000 IU of vitamin $\mathrm{D}_{3}$. In the third experiment, 14 Holstein calves at the University of Idaho (Moscow, ID) dairy herd were administered $4 \mathrm{~mL}$ of saline or a commercial product containing $300 \mathrm{IU}$ of vitamin E, 10,000 IU of vitamin $\mathrm{D}_{3}$, and $100,000 \mathrm{IU}$ of vitamin $\mathrm{A}$ (VITAL E$\mathrm{A}+\mathrm{D}$, Stuart Products, Bedford, TX) at the time of birth. In all experiments, calves received colostrum, were housed under shade, and fed pasteurized waste milk; serum samples were collected at 0 and $7 \mathrm{~d}$ after injection. Serum 25(OH)D was measured by using an ELISA (Eagle Biosciences, Nashua, NH) as previously described (Nelson et al., 2016). Serum 25(OH)D data at $7 \mathrm{~d}$ of age was combined from all experiments and analyzed for effect of the dose of vitamin $\mathrm{D}_{3}$ injected to determine the dose response relationship between vitamin $\mathrm{D}_{3}$ injected and serum $25(\mathrm{OH}) \mathrm{D}$ at $7 \mathrm{~d}$ of age.

\section{RESULTS AND DISCUSSION}

\section{Vitamin D Status of Dairy Cows}

The $25(\mathrm{OH}) \mathrm{D}$ concentrations of 702 serum samples collected from cows on 12 different dairy herds were measured to determine the typical serum $25(\mathrm{OH}) \mathrm{D}$ values for dairy cows. Descriptive data for each herd, including amount of supplemental vitamin D, estimated time spent outdoors during daylight hours, and average serum 25(OH)D concentration, are provided in Table

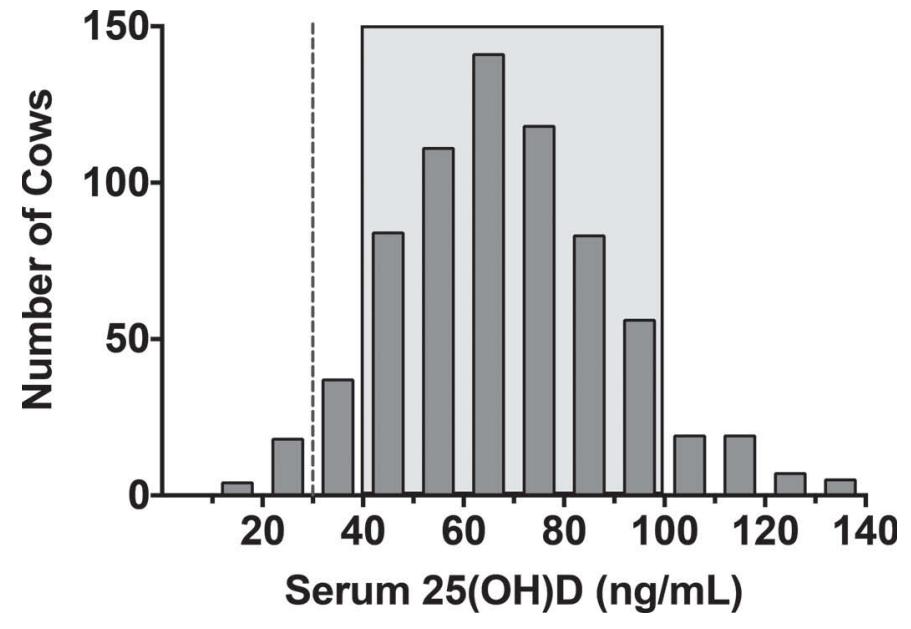

Figure 1. Frequency distribution of serum 25-hydroxyvitamin D $[25(\mathrm{OH}) \mathrm{D}]$ concentrations for mature dairy cows. The frequency of serum samples within each $10-\mathrm{ng} / \mathrm{mL}$ range of $25(\mathrm{OH}) \mathrm{D}$ concentrations is plotted for 702 samples collected from cows in the 12 different dairy herds listed in Table 1 (includes lactating cows 0 to 300 DIM, and pregnant, nonlactating cows). The dotted line represents the threshold for vitamin D insufficiency and the shaded area represents the limits of the 10 th and 90 th percentiles.

1. The average $25(\mathrm{OH}) \mathrm{D}$ concentration of all samples collected was $68 \pm 22 \mathrm{ng} / \mathrm{mL}$ of serum (mean $\pm \mathrm{SD}$ ). The interquartile range was 53 to $82 \mathrm{ng} / \mathrm{mL}$, and the 10th and 90th percentiles were 42 and $96 \mathrm{ng} / \mathrm{mL}$, respectively (Figure 1).

Serum $25(\mathrm{OH}) \mathrm{D}$ concentrations were not affected by season within herds where samples were collected during multiple seasons $(P>0.1$, data not shown; herds located approximately $\left.43^{\circ} \mathrm{N}, 89^{\circ} \mathrm{W}\right)$. Serum $25(\mathrm{OH}) \mathrm{D}$ concentrations also were very similar between herds, with average serum $25(\mathrm{OH}) \mathrm{D}$ of mid- to late-lactation cows in 10 of the 12 herds between approximately 70 to $85 \mathrm{ng} / \mathrm{mL}$ (Figure 2). The serum $25(\mathrm{OH}) \mathrm{D}$ concentrations were also similar between Holstein and Jersey cows sampled in herd $6(71 \pm 18$ and $66 \pm 15 \mathrm{ng} /$ $\mathrm{mL}$, respectively, $P>0.1$ ). All but herd 12 supplemented vitamin $\mathrm{D}_{3}$ at a rate of 30,000 to $50,000 \mathrm{IU} / \mathrm{d}$ in the lactating cow ration (Table 1). For cows receiving 30,000 to 50,000 IU/d and managed similarly (freestall barn with limited sun exposure), we found no relationship between rate of supplementation and average serum $25(\mathrm{OH}) \mathrm{D}(P>0.1)$. The average serum $25(\mathrm{OH}) \mathrm{D}$ of mid- to late-lactation cows from herd 12 that were supplemented with 20,000 IU of vitamin $\mathrm{D}_{3} / \mathrm{d}$, however, was significantly lower than those from other comparable herds (herd 12 vs. herds 9, 10, and 11; $P<0.001$, Figure 2). Furthermore, $22 \%$ of the cows receiving 20,000 $\mathrm{IU} / \mathrm{d}$, the approximate NRC requirement, had serum $25(\mathrm{OH}) \mathrm{D}$ below $30 \mathrm{ng} / \mathrm{mL}$; whereas, $95 \%$ of cows receiving $30,000 \mathrm{IU} / \mathrm{d}$ or more had serum 


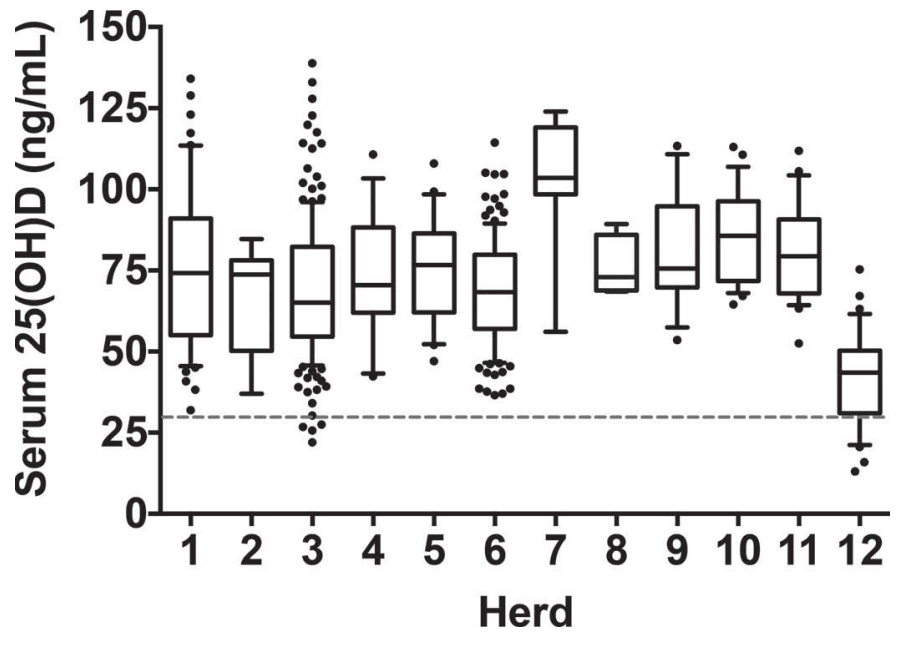

Figure 2. Serum 25-hydroxyvitamin D [25(OH)D] concentrations of mid- to late-lactation cows (100-300 DIM) within each herd listed in Table 1. The dashed line represents the proposed $30-\mathrm{ng} / \mathrm{mL}$ cutoff for vitamin $\mathrm{D}$ insufficiency. Boxes represent the inner quartile range of serum $25(\mathrm{OH}) \mathrm{D}$ concentrations with bars extending to the 5th and 95th percentile and dots representing outliers. Herd 12 supplemented cows with $20,000 \mathrm{IU}$ of vitamin $\mathrm{D}_{3} / \mathrm{d}$, all others were between 30,000 to $50,000 \mathrm{IU} / \mathrm{d}$. The mean serum $25(\mathrm{OH}) \mathrm{D}$ of herd 12 was significantly lower than those of comparable herds (herds 9,10 , and $11 ; P<0.001$ ).

$25(\mathrm{OH}) \mathrm{D}$ above $40 \mathrm{ng} / \mathrm{mL}$ (Figure 2). The lack of association within the 30,000 to $50,000 \mathrm{IU} / \mathrm{d}$ range should be viewed cautiously, as total vitamin $\mathrm{D}$ and actual intakes were unknown and herd was a confounding factor. Controlled experiments are still needed to establish the relationship between serum $25(\mathrm{OH}) \mathrm{D}$ and supplemental vitamin $\mathrm{D}_{3}$ for dairy cows.

Within herds where samples were collected from cows in both early (0 to 30 DIM) and mid to late lactation (100 to $300 \mathrm{DIM})$, serum $25(\mathrm{OH}) \mathrm{D}$ was lower in early-lactation cows than in mid- to late-lactation cows (57 \pm 17 vs. $71 \pm 20 \mathrm{ng} / \mathrm{mL}$, includes herds $1-6$ and 11; $P<0.001 ;$ Figure 3$)$. The supplemental rates of vitamin $\mathrm{D}_{3}$ over the dry period were not collected for most of those herds. Lower vitamin $\mathrm{D}_{3}$ intake over the dry period could explain the lower serum $25(\mathrm{OH}) \mathrm{D}$ in early-lactation cows. However, the close-up dry cow ration for herd 3 was formulated for near the same daily vitamin $\mathrm{D}_{3}$ intake as the lactating ration $(35,000 \mathrm{IU} / \mathrm{d})$ and serum $25(\mathrm{OH}) \mathrm{D}$ concentrations of fresh cows ( 1 to 2 DIM) were lower than that of mid-lactation cows in herd $3(P<0.001)$. Increased $25(\mathrm{OH}) \mathrm{D}$ metabolism and changes in vitamin D-binding protein concentrations also could explain the lower serum 25(OH)D concentrations observed in fresh cows; this, along with vitamin D intake over the transition period, deserve further investigation as potential causes for decreased serum $25(\mathrm{OH}) \mathrm{D}$ in early lactation.
The observations of vitamin D status among dairy cows studied here are similar to those reported by Sorge et al. (2013). Those authors analyzed 25(OH) D in serum samples collected from 160 cows from 6 dairy herds in Minnesota ranging in size from 317 to 710 cows per herd to investigate the relationship between Johne's disease and vitamin D status. The rate of dietary vitamin $\mathrm{D}$ supplementation in the lactating rations for those herds, as determined from analysis of vitamin $\mathrm{D}_{2}$ and vitamin $\mathrm{D}_{3}$ content, ranged from 25,000 to $52,000 \mathrm{IU} / \mathrm{hd} / \mathrm{d}$. The average serum $25(\mathrm{OH})$ D concentration of 80 Mycobacterium avium ssp. paratuberculosis antibody negative-cows was $64 \mathrm{ng} / \mathrm{mL}$. The Mycobacterium avium ssp. paratuberculosis-positive cows tended to have lower serum 25(OH)D (59 ng/ $\mathrm{mL}$ on average), likely as a consequence of decreased intake and absorption of vitamin $\mathrm{D}$. The overall range of serum $25(\mathrm{OH}) \mathrm{D}$ among all samples was from 13 to $100 \mathrm{ng} / \mathrm{mL}$ and serum $25(\mathrm{OH}) \mathrm{D}$ was not associated with rate of supplemental vitamin $\mathrm{D}$. As in the present study, the early-lactation cows in Sorge et al. (2013) had the lowest serum $25(\mathrm{OH}) \mathrm{D}$ concentrations, 54.3 $\mathrm{ng} / \mathrm{mL}$ on average.

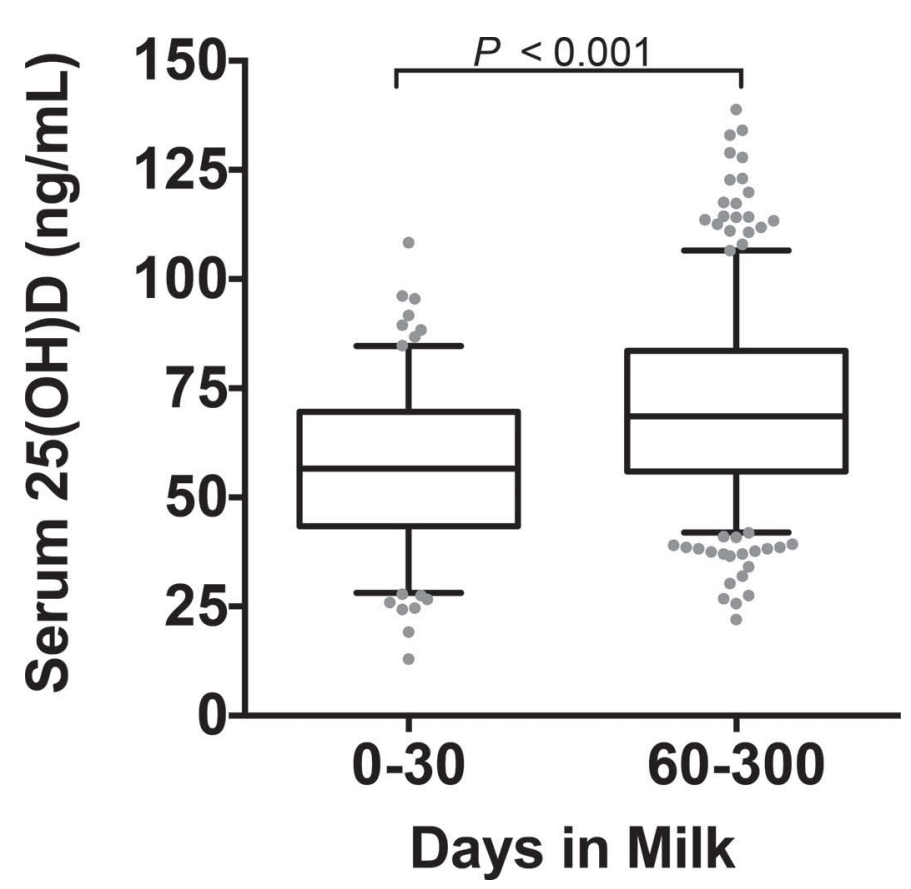

Figure 3. Vitamin D status changes with DIM. Boxes represent the inner quartile range of serum 25-hydroxyvitamin D [25(OH)D] concentrations with bars extending to the 5th and 95th percentile and dots representing outliers for cows within the first 30 DIM $(\mathrm{n}=163)$ and cows between 100 to 300 DIM $(n=424)$. Effect of stage of lactation was analyzed with Proc Mixed of SAS (SAS Institute Inc., Cary, $\mathrm{NC}$ ) with fixed effect of stage and random effect of cow nested in herd. 
It should be noted that legume and grass hay can provide a significant amount of vitamin $\mathrm{D}_{2}$, up to 2,500 $\mathrm{IU} / \mathrm{kg}$ of DM for sun-dried alfalfa hay (Wallis et al., 1958). Estimations of vitamin $\mathrm{D}_{2}$ intake could not be made from the data collected, but individual concentrations of $25(\mathrm{OH}) \mathrm{D}_{2}$ and $25(\mathrm{OH}) \mathrm{D}_{3}$ were measured by mass spectrometry (Heartland Assays, Ames, IA) in serum samples collected from herds $9(\mathrm{n}=6)$ and 10 $(\mathrm{n}=8)$. Concentrations of $25(\mathrm{OH}) \mathrm{D}_{2}$ and $25(\mathrm{OH}) \mathrm{D}_{3}$ were $4.5 \pm 0.5$ and $62.7 \pm 8.7 \mathrm{ng} / \mathrm{mL}$, respectively, for herd 9, and $10.3 \pm 1.6$ and $71.2 \pm 11.3 \mathrm{ng} / \mathrm{mL}$, respectively, for herd 10 . Hence, the concentrations of $25(\mathrm{OH}) \mathrm{D}_{2}$ were approximately 7 and $13 \%$ of the total $25(\mathrm{OH}) \mathrm{D}$ in the samples from the 2 herds. Both herds with data for $25(\mathrm{OH}) \mathrm{D}_{2}$ were confinement dairies in the southeastern United States (approximately $30^{\circ} \mathrm{N}$, $82^{\circ} \mathrm{W}$ ) that fed rations with a low content of hay. The contribution of $25(\mathrm{OH}) \mathrm{D}_{2}$ to the total $25(\mathrm{OH}) \mathrm{D}$ may be greater for cows receiving more high-quality hay than for those observed here; however, that difference may be of little consequence for the total $25(\mathrm{OH}) \mathrm{D}$, as it was quite similar across herds (Table 1).

A concern of some producers and dairy consultants is the vitamin D status of cows housed in barns with limited access to sun exposure. Based on the present data, supplementing between 30,000 to 50,000 IU of vitamin $\mathrm{D}_{3} / \mathrm{d}$ reliably achieves serum $25(\mathrm{OH}) \mathrm{D}$ concentrations between 60 to $80 \mathrm{ng} / \mathrm{mL}$ regardless of housing system. Whether supplementing cows with less than $30,000 \mathrm{IU} / \mathrm{d}$ is adequate is not yet certain, as serum $25(\mathrm{OH}) \mathrm{D}$ concentrations of $22 \%$ of the cows sampled in the herd receiving $20,000 \mathrm{IU}$ of vitamin $\mathrm{D}_{3} / \mathrm{d}$ were below $30 \mathrm{ng} / \mathrm{mL}$ (Figure 2). That observation alone does not warrant changes for vitamin $\mathrm{D}$ recommendations, but does highlight a need for further research. Conversely, consequences of over supplementation of vitamin $\mathrm{D}_{3}$ should be considered. Approximately $10 \%$ of the cows sampled had serum $25(\mathrm{OH}) \mathrm{D}$ concentrations over $100 \mathrm{ng} / \mathrm{mL}$, with some samples approaching 150 $\mathrm{ng} / \mathrm{mL}$. The serum $25(\mathrm{OH}) \mathrm{D}$ threshold for vitamin $\mathrm{D}$ toxicity (i.e., calcification of tissues) has generally been considered to be $200 \mathrm{ng} / \mathrm{mL}$ of serum $25(\mathrm{OH}) \mathrm{D}$ based on observations of cows that received very high doses $\left(15 \times 10^{6} \mathrm{IU}\right)$ of vitamin $\mathrm{D}_{3}$ intramuscularly (Littledike and Horst, 1982; Horst et al., 1994). Weiss et al. (2015), however, did not observe hypercalcemia in cows with serum 25(OH)D concentrations near $270 \mathrm{ng} / \mathrm{mL}$, on average, as a result of feeding $6 \mathrm{mg}$ of $25(\mathrm{OH}) \mathrm{D} / \mathrm{d}$. Thus, the concentrations between 100 to $150 \mathrm{ng} / \mathrm{mL}$ observed here are likely not a concern for overt toxicity, but negative subclinical consequences of excess vitamin D cannot be ruled out and need to be explored.

Likewise, more investigation is needed on vitamin D status around calving. Lower vitamin D intake over the dry period, increased metabolism of $25(\mathrm{OH}) \mathrm{D}$ at calving, and decreased vitamin D-binding protein concentrations are all possible explanations for the decreased serum $25(\mathrm{OH}) \mathrm{D}$ in fresh cows. A lack of data remain for the relationship between supplemental vitamin $\mathrm{D}_{3}$ and serum $25(\mathrm{OH}) \mathrm{D}$ in lactating cattle, as well as whether a relationship exists between vitamin D status and health and production of dairy cattle. Considering the widespread expression of the vitamin $\mathrm{D}$ receptor and newfound roles for vitamin D signaling in physiology of the dairy cow, more information on vitamin D nutrition of lactating cows is needed.

\section{Vitamin D Status of Dairy Heifers}

The serum 25(OH)D concentrations of 12-mo-old Holstein heifers from herds 3 and 9 are listed in Table 1. The heifers from those herds were housed outdoors on dry lots. Serum samples were collected during the month of April $(n=20 /$ herd $)$ and the estimated amounts of daily supplemental vitamin $\mathrm{D}_{3}$ were near 11,000 IU and 12,000 IU for each herd. The corresponding serum $25(\mathrm{OH}) \mathrm{D}$ concentrations on average were $69 \pm 8$ and $82 \pm 18 \mathrm{ng} / \mathrm{mL}$, respectively. The NRC recommendation for dairy heifers is roughly $1,200 \mathrm{IU}$ of vitamin $\mathrm{D}_{3} / \mathrm{kg}$ of $\mathrm{DM}$, or near $9,000 \mathrm{IU} / \mathrm{d}$ for a yearling heifer. From our data, the NRC rate for dairy heifers seems to achieve serum $25(\mathrm{OH}) \mathrm{D}$ concentrations similar to what a lactating cow achieves with 1,200 to 2,000 IU of supplemental vitamin $\mathrm{D}_{3} / \mathrm{kg}$ of DM.

The importance of supplemental vitamin $\mathrm{D}_{3}$ for dairy heifers is underscored by a recent study of serum $25(\mathrm{OH}) \mathrm{D}$ concentrations of feedlot calves (Casas et al., 2015). Serum 25(OH)D concentrations were between 50 and $60 \mathrm{ng} / \mathrm{mL}$, on average, in nearly 200 beef calves coming off summer pasture as they entered the feedlot. In the following month (March), their serum 25(OH) D had dropped to below $20 \mathrm{ng} / \mathrm{mL}$, on average. The calves were in an open feedlot in Nebraska and received between 800 to $1,200 \mathrm{IU}$ of vitamin $\mathrm{D}_{3} / \mathrm{d}$. In another study, serum $25(\mathrm{OH}) \mathrm{D}$ of feedlot steers housed indoors without supplemental vitamin $\mathrm{D}_{3}$ dropped below 10 $\mathrm{ng} / \mathrm{mL}$, whereas those fed $1,860 \mathrm{IU}$ of vitamin $\mathrm{D}_{3} / \mathrm{kg}$ of DM achieved serum 25(OH)D concentration near 70 $\mathrm{ng} / \mathrm{mL}$ (Pickworth et al., 2012). It is often assumed that endogenous vitamin $\mathrm{D}_{3}$ synthesis of cattle housed outdoors along with vitamin $\mathrm{D}_{2}$ from forages is adequate for cattle, but that assumption could be detrimental to dairy heifers. Besides a role for vitamin D in immunity and growth, recent work using rodent models has shown that vitamin D deficiency in the prepubertal period negatively affects reproductive performance (Dicken et al., 2012). As with lactating cows, a lack of data exists on the dose response of serum $25(\mathrm{OH}) \mathrm{D}$ of 
dairy heifers to supplemental vitamin $\mathrm{D}_{3}$, but, according to available data, feeding between 1,200 to $1,500 \mathrm{IU}$ vitamin $\mathrm{D}_{3} / \mathrm{kg}$ of $\mathrm{DM}$ achieves adequate serum $25(\mathrm{OH})$ $\mathrm{D}$ in dairy heifers.

\section{Vitamin D Status of Dairy Calves}

Adequate vitamin D nutrition for young dairy calves is critical because of their rapid growth and metabolism of 25(OH)D (Rajaraman et al., 1997; Nonnecke et al., 2009). Serum 25(OH)D concentrations of preweaned dairy calves across different husbandry and nutritional practices according to age are shown in Figure 4. The average $25(\mathrm{OH}) \mathrm{D}$ concentration of all calves less than $3 \mathrm{~d}$ of age was $15 \pm 11 \mathrm{ng} / \mathrm{mL}$, with a range of 0 to $39 \mathrm{ng} / \mathrm{mL}$. Newborn calves typically have considerably lower serum 25(OH)D than mature animals (Horst and Littledike, 1982); their serum $25(\mathrm{OH}) \mathrm{D}$ also correlates with that of their dams. Thus, the vitamin $\mathrm{D}$ status of the newborn calf is a reflection of dry cow nutrition (Goff et al., 1982; Weiss et al., 2015). Despite the expectation that newborn serum $25(\mathrm{OH}) \mathrm{D}$ will be lower than that of adult animals at birth, the prevalence of calves with serum $25(\mathrm{OH}) \mathrm{D}$ below $20 \mathrm{ng} / \mathrm{mL}$ at birth is a concern. More than $25 \%$ of the newborn calves had serum 25(OH)D concentrations below $10 \mathrm{ng} / \mathrm{mL}$; which, left untreated, puts them at great risk for impaired health and development.

The vitamin D status of calves that received supplemental vitamin $\mathrm{D}_{3}$ or were exposed to sun improved steadily over time (Figure 4, filled symbols). The calves that received milk replacer that contained $6,600 \mathrm{IU}$ of vitamin $\mathrm{D}_{3} / \mathrm{kg}$ of $\mathrm{DM}$ had serum $25(\mathrm{OH}) \mathrm{D}$ concentrations near 50 to $60 \mathrm{ng} / \mathrm{mL}$ at 4 to $6 \mathrm{wk}$ of age. The calves that received milk replacer containing 11,000 $\mathrm{IU} / \mathrm{kg}$ of DM had serum $25(\mathrm{OH}) \mathrm{D}$ concentrations near $100 \mathrm{ng} / \mathrm{mL}$ at $4 \mathrm{wk}$, which is close to what has been previously reported for that rate of supplemental vitamin D (Nonnecke et al., 2010). Likewise, samples collected in mid-April from calves fed pasteurized whole milk and kept outdoors in Florida had serum 25(OH) D concentrations near 40 to $50 \mathrm{ng} / \mathrm{mL}$ at 2 to 6 wk of age. In contrast, serum $25(\mathrm{OH}) \mathrm{D}$ of calves from herds in Florida and Idaho that were fed pasteurized waste milk without supplemental vitamin D and without exposure to midday summer sun remained near or below $15 \mathrm{ng} / \mathrm{mL}$ through $5 \mathrm{wk}$ of age (Figure 4, open symbols). The same was true for calves from a herd in Iowa, where serum 25(OH)D concentrations were $12 \mathrm{ng} / \mathrm{mL}$ on average at approximately $14 \mathrm{~d}$ of age (data not shown, samples collected during month of May). Serum $25(\mathrm{OH}) \mathrm{D}$ of 6 -wk-old calves fed pasteurized waste milk was improved (Figure 4), which would have coincided with intake of starter grain that contained 5,300 IU of vitamin $\mathrm{D}_{3} / \mathrm{kg}$ of $\mathrm{DM}$.

The rapid decline of serum $25(\mathrm{OH}) \mathrm{D}$ of calves fed whole milk or pasteurized waste milk without supplemental vitamin $\mathrm{D}_{3}$ has previously been reported by Rajaraman et al. (1997) and, more recently, by Krueger et al., (2014). Feeding of waste milk and whole milk is a common practice of dairy producers and calf-grower operations (USDA, 2012). Although most of those calves may appear healthy, the consequences of insufficient serum $25(\mathrm{OH}) \mathrm{D}$ concentrations are the impaired actions of intracrine and paracrine vitamin D signaling mechanisms that are not readily apparent. Perhaps most notable for the young calf are the innate immune responses that are activated through intracrine vitamin D signaling. Activation of macrophages of calves in response to innate sensing of pathogen-associated molecules triggers conversion of $25(\mathrm{OH}) \mathrm{D}$ to 1,25 -dihydroxyvitamin $\mathrm{D}$ that induces nitric oxide and $\beta$-defensin

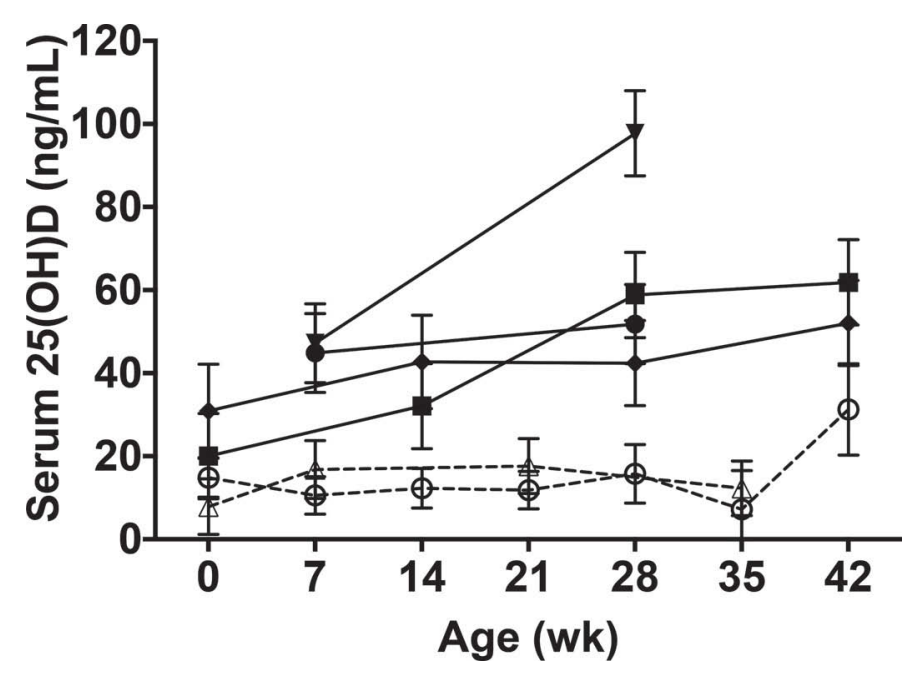

Figure 4. Serum 25-hydroxyvitamin D $[25(\mathrm{OH}) \mathrm{D}]$ of Holstein dairy calves according to various housing and nutrition practices. Each point represents the mean and $95 \% \mathrm{CI}$ of samples from at least 6 calves. The samples collected at 0 wk of age were collected after colostrum consumption. Open triangles $(\Delta)$ and dashed line represent calves from a herd in Idaho fed pasteurized waste milk with no supplemental vitamin $\mathrm{D}_{3}$ limited sun exposure (calves were housed in either hutches or barn and samples were collected in winter). Open circles $(O)$ and dashed line represent calves from a herd in Florida fed pasteurized waste milk with no supplemental vitamin $\mathrm{D}_{3}$ and no direct sun exposure. Filled circles $(\bullet)$ and solid line represent calves in the same herd that received 150,000 IU of vitamin $\mathrm{D}_{3}$ at birth via injection and pasteurized milk supplement that provided 5,000 IU/d. Filled diamonds ( ) and solid line represent calves fed whole milk 3 times/d and kept outdoors in Florida (samples collected in mid-April). Filled squares (ם) and solid line represent calves from a herd in Georgia fed milk replacer containing $6,600 \mathrm{IU} / \mathrm{kg}$ of DM. The calves received $0.8 \mathrm{~kg} / \mathrm{d}$ of milk replacer from 0 to $14 \mathrm{~d}$ and $1.2 \mathrm{~kg} / \mathrm{d}$ milk replacer from 15 to 42 $\mathrm{d}$ and raised under shade. Filled triangles $(\boldsymbol{\nabla})$ and solid line represent calves from a herd in Florida kept outdoors in a group pen and fed ad libitum milk replacer containing $11,000 \mathrm{IU}$ of vitamin $\mathrm{D}_{3} / \mathrm{kg}$ of $\mathrm{DM}$. 
antimicrobial peptide production, innate defenses that are critical for young calves (Nelson et al., 2011; Merriman et al., 2015). The low 25(OH)D concentrations observed in calves fed milk without supplemental vitamin D could impair efficient and rapid activation of those innate defenses and put them at greater disease risk. The key finding being calves fed milk without summer sun exposure require supplemental vitamin $\mathrm{D}_{3}$. According to our data, a rate of $6,000 \mathrm{IU} / \mathrm{kg}$ of $\mathrm{DMI}$ is needed for calves to achieve serum $25(\mathrm{OH}) \mathrm{D}$ concentrations of 50 to $60 \mathrm{ng} / \mathrm{mL}$, which is typical serum $25(\mathrm{OH}) \mathrm{D}$ concentration for beef calves on summer pasture (Casas et al., 2015; Nelson et al., 2016).

\section{Serum 25(OH)D Response of Calves to Supplemental Vitamin $D_{3}$}

The change in serum $25(\mathrm{OH}) \mathrm{D}$ of dairy calves over time in response to supplemental vitamin $\mathrm{D}_{3}$ was predicted using data from multiple experiments (Figure 5). The serum 25(OH)D of calves receiving milk replacer containing only 400 or $1,700 \mathrm{IU}$ of vitamin $\mathrm{D}_{3} / \mathrm{kg}$ of DM changed little over time and remained near or below 20 and $30 \mathrm{ng} / \mathrm{mL}$, respectively, throughout the experiments. In contrast, serum $25(\mathrm{OH}) \mathrm{D}$ of calves receiving 11,000 or $17,900 \mathrm{IU}$ of vitamin $\mathrm{D}_{3} / \mathrm{kg}$ of $\mathrm{DM}$ increased significantly over time to approximately 70 and $170 \mathrm{ng} /$ $\mathrm{mL}$, respectively, by the end of the experiments (dose $\times$ age and dose $\times$ age $\left.^{2}, P<0.001\right)$. Regression analysis of serum $25(\mathrm{OH}) \mathrm{D}$ concentrations from $30 \mathrm{~d}$ of age and older, where age did not have an effect, indicated that serum $25(\mathrm{OH}) \mathrm{D}$ of the calves increased $6.6 \pm 0.7 \mathrm{ng} /$ $\mathrm{mL}$ (slope $\pm 95 \% \mathrm{CI}, P<0.001$ ) for every $1,000 \mathrm{IU}$ of vitamin $\mathrm{D}_{3} / \mathrm{kg}$ of $\mathrm{DM}$ of milk replacer starting from a baseline serum $25(\mathrm{OH}) \mathrm{D}$ of about $16 \mathrm{ng} / \mathrm{mL}$. Thus, a supplementation rate of 6,000 to 7,000 IU of vitamin $\mathrm{D}_{3} / \mathrm{kg}$ of DMI would achieve serum $25(\mathrm{OH}) \mathrm{D}$ concentrations of 50 to $60 \mathrm{ng} / \mathrm{mL}$. This prediction fits well with the data collected from calves on commercial dairies (Figure 4), where calves consuming milk replacer containing $6,600 \mathrm{IU}$ of vitamin $\mathrm{D}_{3} / \mathrm{kg}$ of $\mathrm{DM}$ had serum $25(\mathrm{OH}) \mathrm{D}$ concentrations of $62 \mathrm{ng} / \mathrm{mL}$, on average, at 6 wk of age, and those consuming milk replacer containing $11,000 \mathrm{IU} / \mathrm{kg}$ of DM had serum $25(\mathrm{OH}) \mathrm{D}$ concentration of $98 \mathrm{ng} / \mathrm{mL}$, on average, at 4 wk of age.

With daily supplemental vitamin $\mathrm{D}_{3}$ alone, serum $25(\mathrm{OH}) \mathrm{D}$ gradually increases over a period of 2 to 3 wk (Figures 4 and 5). A more rapid increase during that critical period of a calf's life would seem beneficial, particularly for those born with extremely low serum $25(\mathrm{OH}) \mathrm{D}$. Similar to what was done for daily supplemental vitamin $\mathrm{D}_{3}$, the response of calves to a bolus injection of vitamin $\mathrm{D}_{3}$ at birth was modeled using data from multiple experiments. The regression line for
A
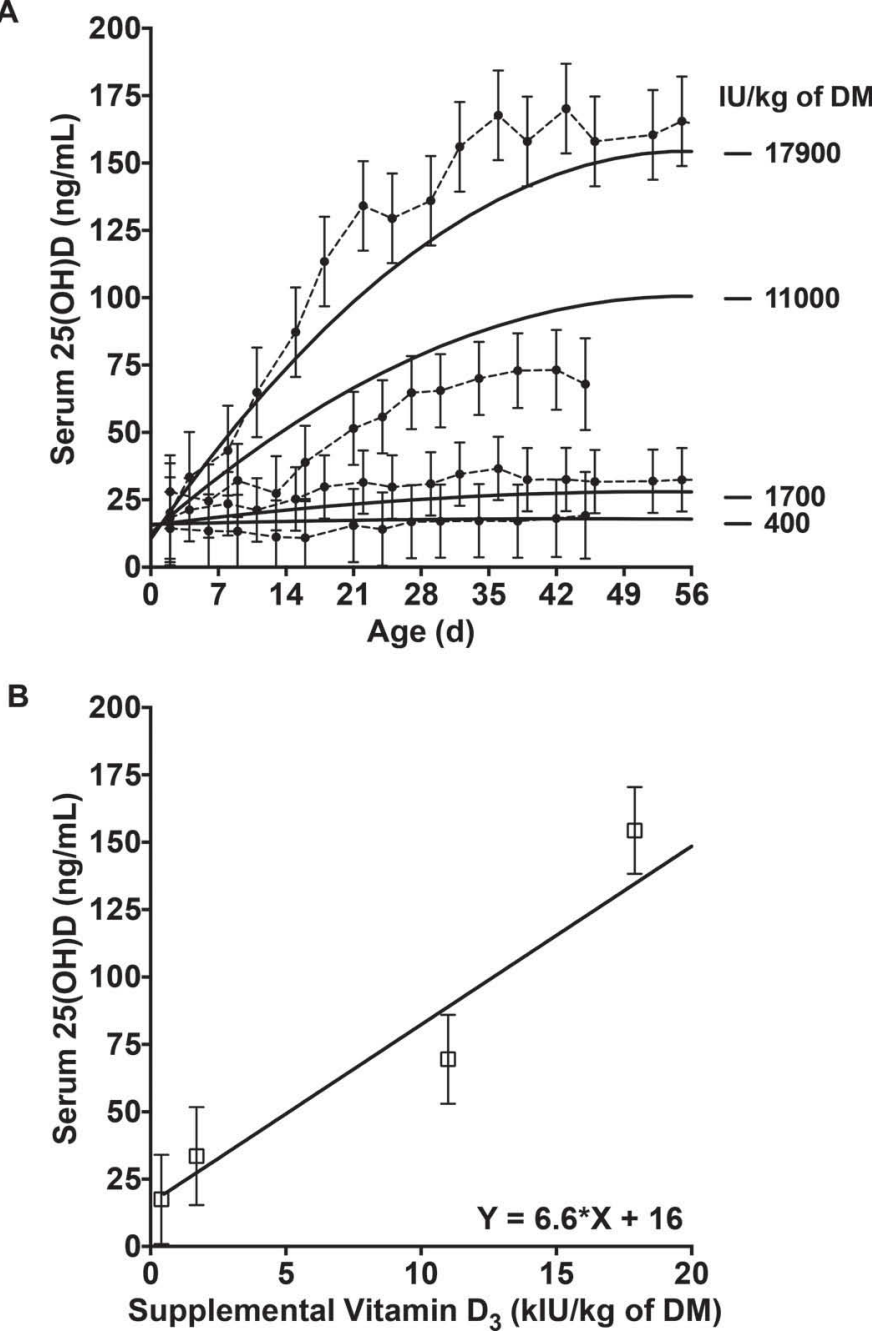

Figure 5. (A) Predicted (solid lines) and observed (dashed lines) serum 25-hydroxyvitamin D [25(OH)D] concentrations of experimental calves in response to rate of supplemental vitamin $\mathrm{D}_{3}$ and day of age. Data represent the outcome of 2 experiments where Holstein bull calves were fed milk replacers containing the increasing amounts of supplemental vitamin $\mathrm{D}_{3}$. In experiment 1 , calves were fed milk replacer containing $1,700(\mathrm{n}=16)$ or $17,900 \mathrm{IU}$ of vitamin $\mathrm{D}_{3} / \mathrm{kg}$ of DM (n $=8)$. In experiment 2 , calves were fed $400(\mathrm{n}=12)$ or $11,000 \mathrm{IU}$ of vitamin $\mathrm{D}_{3} / \mathrm{kg}$ of DM $(\mathrm{n}=12)$. Data points and error bars represent the mean and $95 \%$ CI for each group according to day of age. The equation of the predicted response was $[25(\mathrm{OH}) \mathrm{D}]=16.02 \mathrm{ng} / \mathrm{mL}+(-0.00031$ $\times$ IU of vitamin $\left.\mathrm{D}_{3}\right)+(-0.024 \times \mathrm{d})+\left(0.00029 \times \mathrm{IU}\right.$ of vitamin $\mathrm{D}_{3}$ $\times \mathrm{d})+\left(-2.59 \times 10^{-6} \times \mathrm{IU}\right.$ of vitamin $\left.\mathrm{D}_{3} \times \mathrm{d}^{2}\right) .(\mathrm{B})$ The solid line represents the slope and intercept of the regression analysis of serum $25(\mathrm{OH}) \mathrm{D}$ concentrations of samples collected at $30 \mathrm{~d}$ of age and older as a function of supplemental vitamin $\mathrm{D}_{3}$. The slope $(6.6 \mathrm{ng} / \mathrm{mL}$ per kIU of vitamin $\left.\mathrm{D}_{3}\right)$ and intercept $(16.1 \mathrm{ng} / \mathrm{mL})$ were significant $(P<$ $0.001)$. The symbols and error bars represent the observed means with $95 \%$ CI of samples from calves in each group at $30 \mathrm{~d}$ of age and older.

serum $25(\mathrm{OH}) \mathrm{D}$ at $7 \mathrm{~d}$ after injection with vitamin $\mathrm{D}_{3}$ predicted an increase of about $30 \pm 8 \mathrm{ng} / \mathrm{mL}$ (slope \pm $95 \% \mathrm{CI}, P<0.001)$ for every $100,000 \mathrm{IU}$ of vitamin $\mathrm{D}_{3}$ administered starting from a baseline serum $25(\mathrm{OH}) \mathrm{D}$ of $11 \mathrm{ng} / \mathrm{mL}$ (Figure 6). 


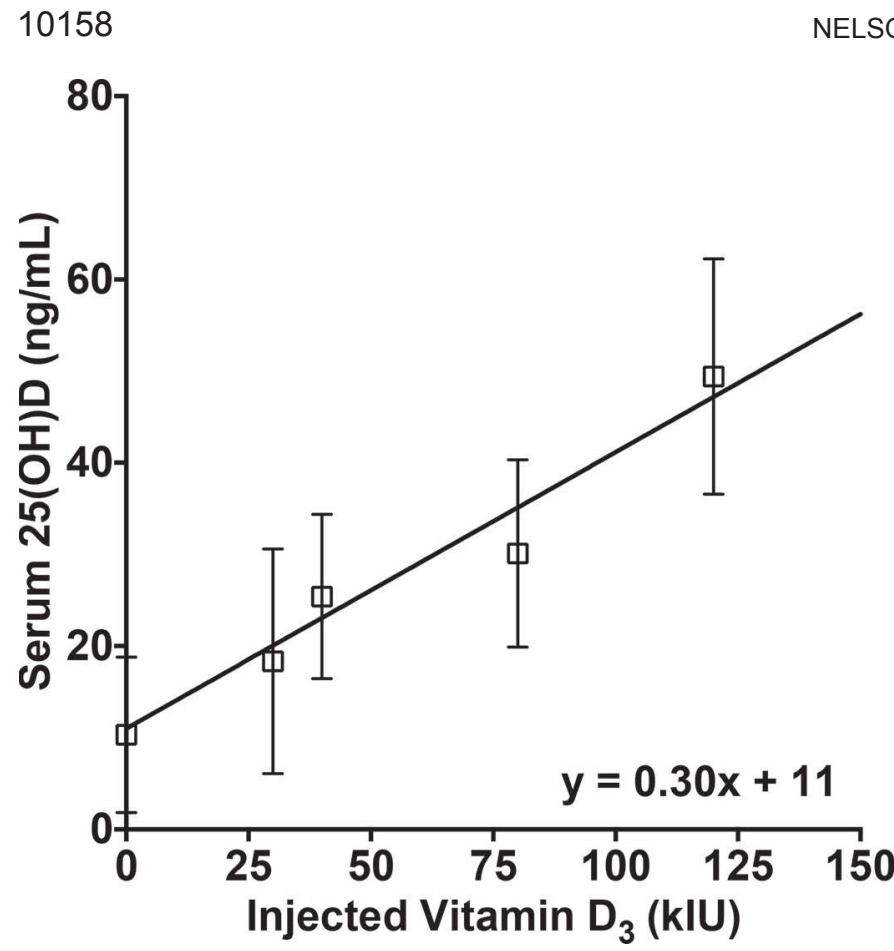

Figure 6. Prediction of serum 25-hydroxyvitamin D $[25(\mathrm{OH}) \mathrm{D}]$ in response to subcutaneous vitamin $\mathrm{D}_{3}$ injection. In 3 separate experiments, calves were administered various amounts of vitamin $\mathrm{D}_{3}$ via subcutaneous injection at birth and serum $25(\mathrm{OH}) \mathrm{D}$ was measured at $7 \mathrm{~d}$ of age. In the first experiment, Holstein bull calves received 0 ( $\mathrm{n}$ $=6)$ or $30,000 \mathrm{IU}$ of vitamin $\mathrm{D}_{3}(\mathrm{n}=3)$. In the second experiment, Holstein bull calves received $0(\mathrm{n}=8), 80,000(\mathrm{n}=5)$, or 120,000 $\mathrm{IU}(\mathrm{n}=3)$ of vitamin $\mathrm{D}_{3}$. In the third experiment, Holstein bull and heifer calves received saline injection or $40,000 \mathrm{IU}$ of vitamin $\mathrm{D}_{3}$ from a commercially available vitamin $\mathrm{A}, \mathrm{D}$, and $\mathrm{E}$ solution ( $\mathrm{n}=7$ /group). In each experiment, calves were fed pasteurized waste milk without any supplemental vitamin $\mathrm{D}_{3}$. The symbols and error bars represent the means with $95 \%$ CI of serum $25(\mathrm{OH}) \mathrm{D}$ measured in samples collected at $7 \mathrm{~d}$ postinjection for each amount of vitamin $\mathrm{D}_{3}$ injected. The solid line represents regression line with a slope and intercept of $(0.3$ $\mathrm{ng} / \mathrm{mL}$ per $\mathrm{kIU}$ of vitamin $\left.\mathrm{D}_{3}\right)$ and intercept $(11.0 \mathrm{ng} / \mathrm{mL})$ that were significant $(P<0.001)$.

Krueger et al. (2014) reported a similar response where serum $25(\mathrm{OH}) \mathrm{D}$ of calves injected with 40,000 IU of vitamin $\mathrm{D}_{3}$ at birth increased from approximately $20 \mathrm{ng} / \mathrm{mL}$ at birth to $40 \mathrm{ng} / \mathrm{mL} 7 \mathrm{~d}$ later. Those calves were fed pasteurized waste milk and, in the absence of continued vitamin $\mathrm{D}$ supplementation, their serum $25(\mathrm{OH}) \mathrm{D}$ dropped to $30 \mathrm{ng} / \mathrm{mL}$ after $14 \mathrm{~d}$ and $15 \mathrm{ng} /$ $\mathrm{mL}$ at $35 \mathrm{~d}$. In a separate study, those authors showed that calves given 150,000 IU of injectable vitamin $\mathrm{D}_{3}$ at birth followed by 5,000 IU of supplemental vitamin $\mathrm{D}_{3} / \mathrm{d}\left(\sim 7,500 \mathrm{IU}\right.$ of vitamin $\mathrm{D}_{3} / \mathrm{kg}$ of $\mathrm{DM}$, in combination with vitamins $\mathrm{A}$ and $\mathrm{E}$ ) increased from an average serum $25(\mathrm{OH}) \mathrm{D}$ of $30 \mathrm{ng} / \mathrm{mL}$ at birth to near $100 \mathrm{ng} /$ $\mathrm{mL}$ at 7 and $14 \mathrm{~d}$ of age (Krueger et al., 2016). In contrast, serum $25(\mathrm{OH}) \mathrm{D}$ of control calves dropped from $30 \mathrm{ng} / \mathrm{mL}$ at birth to less than $20 \mathrm{ng} / \mathrm{mL}$ at $14 \mathrm{~d}$ of age. Ultimately, those authors demonstrated that a bolus injection of vitamin $\mathrm{D}_{3}$ at birth followed by daily supplemental vitamin $\mathrm{D}_{3}$ is an effective means of increasing serum $25(\mathrm{OH}) \mathrm{D}$ of calves. Assuming an initial $25(\mathrm{OH})$ D concentration of 15 to $25 \mathrm{ng} / \mathrm{mL}$ for most calves at birth, and depending on the rate of daily supplemental vitamin $\mathrm{D}_{3}$, an initial injection of 50,000 to $100,000 \mathrm{IU}$ of vitamin $\mathrm{D}_{3}$ at birth should be adequate to achieve vitamin D sufficiency. Caution must be used, however, with injectable vitamin formulations, as most products on the market contain vitamins $\mathrm{A}, \mathrm{D}$, and $\mathrm{E}$ in various combinations. Intramuscular injections of excessive vitamin A (i.e., $2 \times 10^{6} \mathrm{IU}$ ) caused the development of hyena disease in calves (Takaki et al., 1996; Woodard et al., 1997). Data from the experiments reported by Krueger et al. (2014, 2016) also indicate that bolus vitamin A injections are not necessary if adequate vitamin A is provided in the diet. Consequently, use of injectable vitamin products should carefully consider the background, diet, and management of the calf.

The serum 25(OH)D concentrations that support optimal growth and health of calves are not yet fully known; thus, recommendations for supplemental vitamin D should not be viewed as definitive at this time. Concentrations below $30 \mathrm{ng} / \mathrm{mL}$ of serum have been proposed as a good benchmark for insufficiency (Norman, 2008; Adams and Hewison, 2010). Conversely, calves with average serum $25(\mathrm{OH}) \mathrm{D}$ above $170 \mathrm{ng} /$ $\mathrm{mL}$ were not protected from respiratory syncytial virus infection better than calves with $30 \mathrm{ng} / \mathrm{mL}$ serum $25(\mathrm{OH}) \mathrm{D}$. Future experiments need to examine more fully the relationship between serum $25(\mathrm{OH}) \mathrm{D}$, disease incidence (epidemiological and experimental diseases), vitamin D-associated immune functions (nitric oxide and $\beta$-defensin production of macrophages), and overall production. For the time being, a moderate range of 40 to $80 \mathrm{ng} / \mathrm{mL}$ of serum $25(\mathrm{OH}) \mathrm{D}$ seems to be a reasonable range based on serum $25(\mathrm{OH}) \mathrm{D}$ concentrations of calves on summer pasture. Milk replacers often contain about $11,000 \mathrm{IU}$ of vitamin $\mathrm{D}_{3} / \mathrm{kg}$ of $\mathrm{DM}$, which somewhat exceeds serum $25(\mathrm{OH}) \mathrm{D}$ of calves on pasture but is satisfactory based on current state of knowledge. In contrast, producers that raise calves on milk need to adopt the practice of adding supplemental vitamin $\mathrm{D}_{3}$, as discussed. In addition, a bolus vitamin D supplement at birth would help to quickly increase the vitamin $\mathrm{D}$ status of newborn calves.

\section{CONCLUSIONS}

The current practices for dietary vitamin $\mathrm{D}_{3}$ supplementation in the dairy industry seem to be adequate for cows and heifers, with the $25(\mathrm{OH}) \mathrm{D}$ concentrations of most animals ranging between 50 to $80 \mathrm{ng} / \mathrm{mL}$ of serum. In fact, supplementing cows at rates well above 
the NRC recommendation of $21,000 \mathrm{IU}$ of vitamin $\mathrm{D}_{3} / \mathrm{d}$ for mature cows, such as 40,000 to 50,000 IU/d, may be more than necessary. In contrast, supplementation with $21,000 \mathrm{IU} / \mathrm{d}$ may not be adequate based on limited observations reported here. Future research needs to explore the relationship between supplemental vitamin $\mathrm{D}_{3}$ and serum $25(\mathrm{OH}) \mathrm{D}$ of dairy cows with regards to key endpoints of disease incidence, fertility, and milk production, along with consideration of the long-term effects of high serum $25(\mathrm{OH}) \mathrm{D}$ concentrations that occur in a portion of cows under current practices. In regard to dairy calves, the amount of vitamin $\mathrm{D}_{3}$ in typical milk replacers is adequate but needs to be studied further to determine amounts needed for optimal growth and health. Calves raised on a milk diet, however, are prone to vitamin D deficiency, as milk is very low in vitamin $\mathrm{D}$ content. It is recommended that producers raising calves on milk should provide supplemental vitamin $\mathrm{D}_{3}$ at a rate of 6,000 to 10,000 $\mathrm{IU} / \mathrm{kg}$ of DM. A 50,000 to 100,000 IU bolus of vitamin $\mathrm{D}_{3}$ at birth, whether calves are fed milk or milk replacer diets, would also help to quickly achieve vitamin D sufficiency in newborn calves. Altogether, the recommendations provided here are intended to maintain vitamin D sufficiency as defined by serum $25(\mathrm{OH}) \mathrm{D}$ concentrations. Additional research is needed to identify whether correlations exist between serum $25(\mathrm{OH}) \mathrm{D}$ and health and productivity of cattle.

\section{ACKNOWLEDGMENTS}

The authors thank Duane Zimmerman and Derrel Hoy (USDA-ARS, Ames, IA) for sample collection and 25(OH)D RIA analysis, Kathryn Merriman (University of Florida) and Darren Zimmerman (Sunrise Veterinary Services, Reedsburg, WI) for sample collection, and each of the dairy producers and nutritionists that contributed samples or information.

\section{REFERENCES}

Adams, J. S., and M. Hewison. 2010. Update in vitamin D. J. Clin. Endocrinol. Metab. 95:471-478.

Bechdel, S. I., N. W. Hillston, and N. B. Guerrant. 1937. The vitamin D requirement (U.S.P Units) for growth and well-being of calves from birth to six months of age. J. Dairy Sci. 20:434.

Bechtel, H. E., E. T. Hallman, and C. F. Huffman. 1935. The pathology of rickets in dairy calves. J. Dairy Sci. 18:432-433.

Casas, E., J. D. Lippolis, L. A. Kuehn, and T. A. Reinhardt. 2015. Seasonal variation in vitamin D status of beef cattle reared in the central United States. Domest. Anim. Endocrinol. 52:71-74.

DeLuca, H. F. 1971. Vitamin D: A new look at an old vitamin. Nutr. Rev. 29:179-181.

Dicken, C. L., D. D. Israel, J. B. Davis, Y. Sun, J. Shu, J. Hardin, and G. Neal-Perry. 2012. Peripubertal vitamin D(3) deficiency delays puberty and disrupts the estrous cycle in adult female mice. Biol. Reprod. 87:51.
FASS. 2010. Guidelines for the Care and Use of Agricultural Animals in Research and Teaching. 3rd ed. FASS Inc., Champaign, IL.

Fraser, D. R., and E. Kodicek. 1970. Unique biosynthesis by kidney of a biological active vitamin D metabolite. Nature 228:764-766.

Goff, J. P., R. L. Horst, and E. T. Littledike. 1982. Effect of the maternal vitamin D status at parturition on the vitamin D status of the neonatal calf. J. Nutr. 112:1387-1393.

Hollis, B. W. 2005. Circulating 25-hydroxyvitamin D levels indicative of vitamin D sufficiency: Implications for establishing a new effective dietary intake recommendation for vitamin D. J. Nutr. 135:317-322.

Hollis, B. W., J. Q. Kamerud, S. R. Selvaag, J. D. Lorenz, and J. L. Napoli. 1993. Determination of vitamin D status by radioimmunoassay with an ${ }^{125}$ I-labeled tracer. Clin. Chem. 39:529-533.

Horst, R. L., J. P. Goff, and T. A. Reinhardt. 1994. Calcium and vitamin D metabolism in the dairy cow. J. Dairy Sci. 77:1936-1951.

Horst, R. L., and E. T. Littledike. 1982. Comparison of plasma concentrations of vitamin $\mathrm{D}$ and its metabolites in young and aged domestic animals. Comp. Biochem. Physiol. B 73:485-489.

Horst, R. L. T. A. Reinhardt, J. R. Russell, and J. L. Napoli. 1984. The isolation and identification of vitamin D2 and vitamin D3 from Medicago sativa (alfalfa plant). Arch. Biochem. Biophys. 231:67-71.

Huffman, C. F., and C. W. Duncan. 1935. A preliminary study of the vitamin D requirement of calves when fed natural milk as the source of this vitamin. J. Dairy Sci. 18:432.

Hymøller, L., and S. K. Jensen. 2011. Vitamin D(2) impairs utilization of vitamin $\mathrm{D}(3)$ in high-yielding dairy cows in a cross-over supplementation regimen. J. Dairy Sci. 94:3462-3466.

Krueger, L. A., D. C. Beitz, K. Onda, M. Osman, M. R. O'Neil, S. Lei, F. H. Wattoo, R. L. Stuart, H. D. Tyler, and B. Nonnecke. 2014 Effects of D- $\alpha$-tocopherol and dietary energy on growth and health of preruminant dairy calves. J. Dairy Sci. 97:3715-3727.

Krueger, L. A., T. A. Reinhardt, D. C. Beitz, R. L. Stuart, and J. R. Stabel. 2016. Effects of fractionated colostrum replacer and vitamins $\mathrm{A}, \mathrm{D}$, and $\mathrm{E}$ on haptoglobin and clinical health in neonatal Holstein calves challenged with Mycobacterium avium ssp. paratuberculosis. J. Dairy Sci. 99:2884-2895.

Littledike, E. T., and R. L. Horst. 1982. Vitamin D3 toxicity in dairy cows. J. Dairy Sci. 65:749-759.

Liu, P. T., S. Stenger, H. Li, L. Wenzel, B. H. Tan, S. R. Krutzik, M. T. Ochoa, J. Schauber, K. Wu, C. Meinken, D. L. Kamen, M. Wagner, R. Bals, A. Steinmeyer, U. Zugel, R. L. Gallo, D. Eisenberg, M. Hewison, B. W. Hollis, J. S. Adams, B. R. Bloom, and R. L. Modlin. 2006. Toll-like receptor triggering of a vitamin D-mediated human antimicrobial response. Science 311:1770-1773.

Lund, J., and H. F. DeLuca. 1966. Biologically active metabolite of vitamin D3 from bone, liver, and blood serum. J. Lipid Res. 7:739-744.

Merriman, K. E., M. F. Kweh, J. L. Powell, J. D. Lippolis, and C. D. Nelson. 2015. Multiple $\beta$-defensin genes are upregulated by the vitamin D pathway in cattle. J. Steroid Biochem. Mol. Biol. 154:120-129

Nelson, C. D., B. J. Nonnecke, T. A. Reinhardt, W. R. Waters, D. C. Beitz, and J. D. Lippolis. 2011. Regulation of Mycobacterium-specific mononuclear cell responses by 25 -hydroxyvitamin D3. PLoS One 6:e21674

Nelson, C. D., J. L. Powell, D. M. Price, M. J. Hersom, J. V. Yelich, M. E. Drewnoski, S. L. Bird, and G. A. Bridges. 2016. Assessment of serum 25-hydroxyvitamin D concentrations of beef cows and calves across seasons and geographical locations. J. Anim. Sci. http://dx.doi.org/10.2527/jas.2016-0611.

Nelson, C. D., T. A. Reinhardt, J. D. Lippolis, R. E. Sacco, and B. J. Nonnecke. 2012. Vitamin D signaling in the bovine immune system: A model for understanding human vitamin D requirements. Nutrients 4:181-196.

Nelson, C. D., T. A. Reinhardt, T. C. Thacker, D. C. Beitz, and J. D. Lippolis. 2010. Modulation of the bovine innate immune response by production of 1 alpha,25-dihydroxyvitamin $\mathrm{D}(3)$ in bovine monocytes. J. Dairy Sci. 93:1041-1049. 
Nonnecke, B. J., M. R. Foote, B. L. Miller, D. C. Beitz, and R. L. Horst. 2010. Short communication: Fat-soluble vitamin and mineral status of milk replacer-fed dairy calves: Effect of growth rate during the preruminant period. J. Dairy Sci. 93:2684-2690.

Nonnecke, B. J., T. A. Reinhardt, and W. R. Waters. 2009. Short communication: The preruminant calf as a model for characterizing the effects of vitamin D status in the neonate. J. Dairy Sci. 92:5692-5696.

Norman, A. W. 2008. From vitamin D to hormone D: Fundamentals of the vitamin D endocrine system essential for good health. Am. J. Clin. Nutr. 88:491S-499S.

NRC. 2001. Nutrient Requirements of Dairy Cattle. 7th rev. ed. Natl. Acad. Press, Washington, DC.

Pickworth, C. L., S. C. Loerch, and F. L. Fluharty. 2012. Restriction of vitamin A and D in beef cattle finishing diets on feedlot performance and adipose accretion. J. Anim. Sci. 90:1866-1878.

Rajaraman, V., B. J. Nonnecke, and R. L. Horst. 1997. Effects of replacement of native fat in colostrum and milk with coconut oil on fat-soluble vitamins in serum and immune function in calves. J. Dairy Sci. 80:2380-2390.

Rupel, I. W., Bohsted, G. and E.B. Hart. 1932. The role of vitamin D in the nutrition of the dairy calf. Pages 137-141 in Proc. American Society of Animal Nutrition. 10.2134/jas1932.19321137x.

Sommerfeldt, J. L., J. L. Napoli, E. T. Littledike, D. C. Beitz, and R. L. Horst. 1983. Metabolism of orally administered $\left[{ }^{3} \mathrm{H}\right]$ ergocalciferol and $\left[{ }^{3} \mathrm{H}\right]$ cholecalciferol by dairy calves. J. Nutr. 113:2595-2600.

Sorge, U. S., T. Molitor, J. Linn, D. Gallaher, and S. W. Wells. 2013 Cow-level association between serum 25-hydroxyvitamin D con- centration and Mycobacterium avium subspecies paratuberculosis antibody seropositivity: A pilot study. J. Dairy Sci. 96:1030-1037.

Takaki, H., S. Fukuda, H. Iida, J. Sato, R. Sato, and Y. Naito. 1996. Experimental studies on bovine Hyena disease induced by administration of excessive vitamin AD3E premix, vitamin A, or vitamin D3. J. Vet. Med. Sci. 58:311-316.

USDA. 2012. Dairy Heifer Raiser 2011, An overview of operations that specialize in raising dairy heifers. \#63.1012 ed. USDA-APHIS, National Animal Health Monitoring System (NAHMS), Ft. Collins, $\mathrm{CO}$.

Wallis, G. C. 1937. Effects of a vitamin D deficiency on mature dairy cows. J. Dairy Sci. 20:436.

Wallis, G. C. 1946. Vitamin D deficiency in dairy cows. South Dakota Agricultural Experiment Station Bulletin, No. 372. http:// openprairie.sdstate.edu/agexperimentsta_bulletins/372 .

Wallis, G. C., G. H. Kennedy, and R. H. Fishman. 1958. The vitamin D content of roughages. J. Anim. Sci. 17:410-415.

Weiss, W. P. 1998. Requirements of fat-soluble vitamins for dairy cows: A review. J. Dairy Sci. 81:2493-2501.

Weiss, W. P., E. Azem, W. Steinberg, and T. A. Reinhardt. 2015. Effect of feeding 25-hydroxyvitamin $\mathrm{D}_{3}$ with a negative cation-anion difference diet on calcium and vitamin $\mathrm{D}$ status of periparturient cows and their calves. J. Dairy Sci. 98:5588-5600.

Woodard, J. C., G. A. Donovan, and L. W. Fisher. 1997. Pathogenesis of vitamin (A and D)-induced premature growth-plate closure in calves. Bone 21:171-182. 